\title{
DO FIRMS FACING INCREASES IN FINANCIAL CONSTRAINTS TEND TO GENERATE CASH THROUGH TAX AVOIDANCE EMPIRICAL EVIDENCE FROM INDONESIA PUBLICLY LISTED FIRMS
}

\author{
John Erhan Prasetyo Hermawan ${ }^{\mathrm{a}}$, Riko Riandoko ${ }^{\mathrm{b}}$ \\ a Polytechnic of State Finance STAN, South Tangerang. E-mail: johnerhan.prasetyo@pajak.go.id \\ b Polytechnic of State Finance STAN, South Tangerang. E-mail: riandoko@stan.ac.id
}

\section{ABSTRACT}

This study examines the effect of increases in financial constraints measured at both firm-specific and macroeconomic level on corporate tax avoidance behaviour. Based on a hand-collected sample of 60 publicly listed firms on Indonesia Stock Exchange (IDX) from the year 2009 to 2016, our regression result shows that firms facing increased firm-specific constraints exhibit lower cash effective tax rates ranging from 0.55 to 9.57 percent which equate to between 0.60 and 10.29 percent of operating cash flows, whereas at macroeconomic constraints do not. The firm-specific constraints result is consistent with our hypothesis and Edwards, et al. (2016), whereas macroeconomic constraints result is inconsistent. Nevertheless, its inconsistency can be caused by several factors, i.e.: (1) the change of corporate tax rate from 28 to 25 percent as fiscal policy after the impact of Global Financial Crisis 2008. It could reduce tax avoidance behaviour; (2) Indonesian Go Public Information Centre stated that the purpose of the firms' Initial Public Offering (IPO) is not only to finance the firms' operation due to increases in financial constraints, but also to increase firm value, improve corporate image, grow employee loyalty, maintain business continuity and get tax incentives; (3) the equity financing in Indonesia is more related to equity participation activities conducted among shareholders that's not listed on the stock or bond markets, e.g. private placement, joint venture, mergers and acquisitions. 


\section{INTRODUCTION}

Tax ratio is one of the commonly measured of country's tax revenue performance (Setiyaji and Amir, 2005). In accordance with World Bank data, the average of Indonesia's tax ratio from the year 2008 to 2016 is 11.70 percent.
The Minister of Finance, Sri Mulyani, as quoted from wartaekonomi.co.id (December 20, 2017) said that Indonesia's tax ratio is at 11 percent level. Furthermore, she revealed that this ratio is the lowest ratio in the world. Compared to ASEAN Countries, Indonesia's tax ratio is left behind.

Figure 1 Tax Ratio of Indonesia and Average ASEAN Countries

Source: World Bank

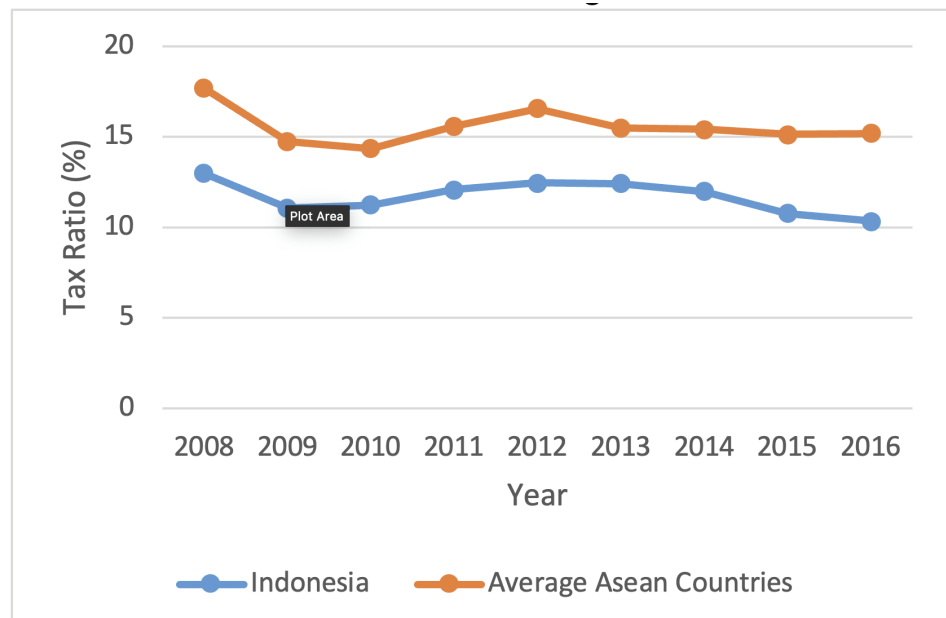

The fundamental issues in Indonesia's taxation is the leakage of tax revenue due to tax avoidance and tax evasion activities (Darussalam, 2017). Besley and Person (2014) similarly conclude that one of the key factors that lead to poor tax revenue performance in developing countries is tax avoidance activities.

Hanlon and Heitzman (2010) explain that one of the tax avoidance strategies is cash tax savings. Cash tax savings is described by reducing the amount of cash paid to tax authority using deferral strategies or permanent different mechanisms (Leone, 2008). Cash tax savings can be viewed as a source of financing which is less costly than other cost-cutting techniques because it does not adversely impact the firm's operation (Edwards, et al., 2016). According to Chen and Lai (2012), firms facing financial constraints tend to generate cash through tax avoidance.

Whited and Wu (2006) describe that firm facing financial constraints is experiencing an increase in cost of external financing or difficulty of accessing external fund. Edwards, et al., (2016) argue that the increases in financial constraints will affect corporate tax avoidance strategies by reducing the amount of cash that should be paid to the tax authority. This mechanism is called as cash tax savings.

Financial constraints can be caused by internal and external factors. The internal factors occurred if the firms lack of 
liquidity to finance its operation leads to the tendency of bankruptcy (Altman, 1968) and if the firms meet the difficulty to finance its investment (Kaplan and Zingales, 1997; Whited and $\mathrm{Wu}$, 2006). The external factors occurred from the macroeconomic shocks, e.g. economic crisis, economic contraction, stock markets crash and banking crisis (Petersen and Rajan, 2002; Degryse and Ongena, 2005). It's important to understand the interplay between firm level as internal factors and macroeconomic shocks as external factors because it can simultaneously affect corporate tax avoidance strategies, thus determine the magnitude of a government's tax revenue (Edwards, et al., 2013).

The Global Financial Crisis 2008 was one of the macroeconomic shocks that had impacted global economic activity (OECD, 2009). According to Glick and Spiegel (2010), the impact was also experienced by the trade and financial channels in Asia. The trade channels impact is significantly greater than financial channels in Indonesia (Indonesia Economic Outlook, 2009, 66). Furthermore, it is explained that the lack of intensity of the financial channels impact is due to low placement of banking funds and domestic financial institutions' troubled asset in the global financial market.

One of the trade channels impacts is the decline of export performance (Indonesia Economic Outlook, 2009, 61). Basri (2013) says that the impact of crisis in Indonesia is a significantly declining in export growth. The export-oriented textile industry is one of the industries affected by the crisis (Indonesia Economic Outlook, 2009, 41). On the other hand, the impact was also said by the Chairman of the Central Java Entrepreneur Association, Djoko Wahyudi, as quoted from antaranews.com (December 20, 2017). He said that by the end of 2008 there was a garment factory that reduced the number of employees up to 2,000 workers in Semarang, Central Java because of the decreased export market.

The increases in financial constraints of textile industry due to the crisis causes firms in the industry tend to generate cash through tax avoidance (Edwards, et al., 2016). Juda et al. (2000) explain that firms can use internal funding sources in the postcrisis period. The amount of cash tax savings can be reflected in the lower cash effective tax rate (Cash ETR). However, in figure 2, the fact of the average Cash ETR of Indonesia's textile industry is even higher from 2007 to 2015.

Edwards, et al. (2016) proves that the increases in financial constraints have a positive association with cash tax savings. However, In Indonesia, the case of textile industry facing increases in financial constraints did not tend to generate cash through tax avoidance. Thus this phenomenon indicates the need to be further verified by taking larger sample. In addition, the research that empirically test the effect of increases in financial constraints on 
Figure 2 The Average Cash ETR of Textile Industry in Indonesia Public Listed Firms

Source: Financial Statement of Textile Industry for the Years 2007 - 2015

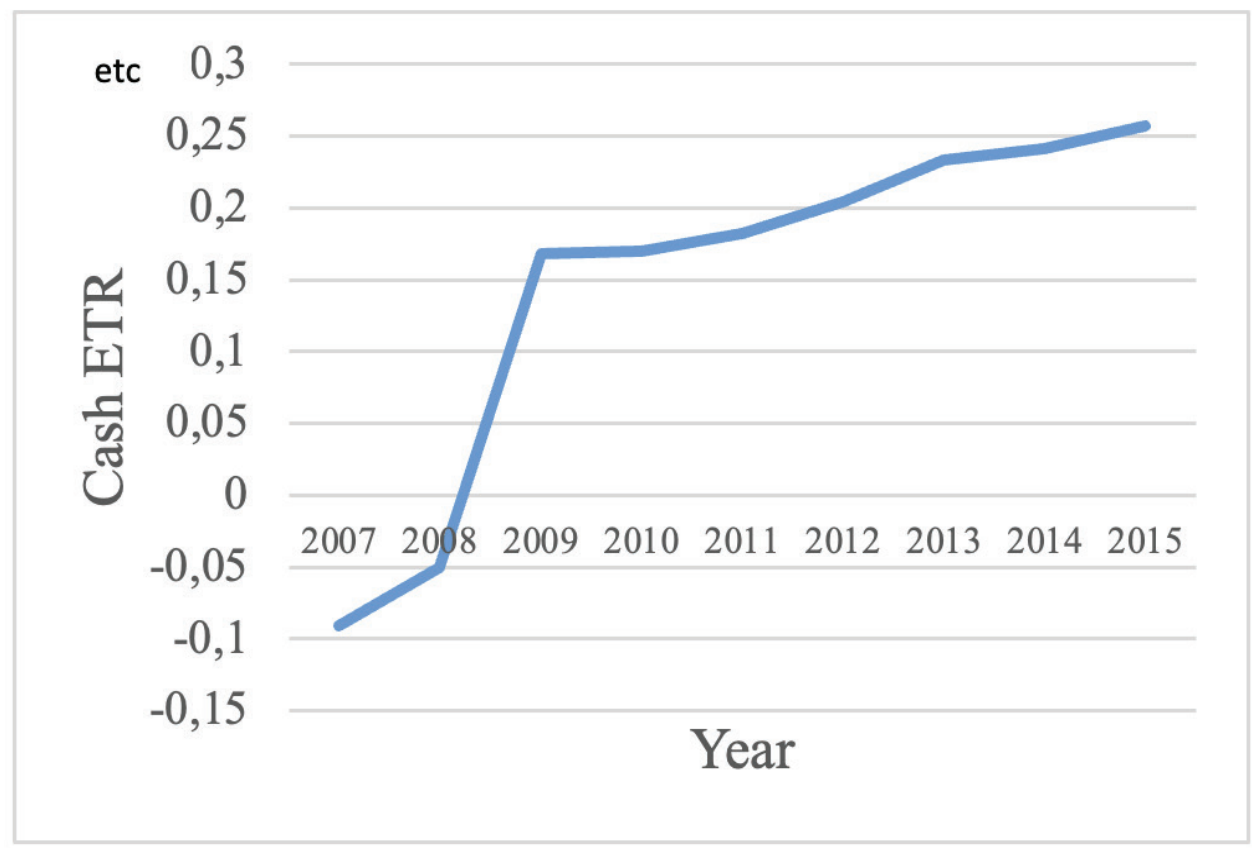

cash tax savings has not been done in Indonesia. Therefore, in this study, we examine the effect of the increases in financial constraints on cash tax savings in Indonesia.

The sample of this study consists of publicly listed firms in Indonesia over the sample period of 2009 - 2016. Using Ordinary Least Square (OLS) model, we found that increases in financial constraints measured by the change of Altman Z-Score and KZ-Index as proxies firm-specific constraints has significant positive effect on cash tax savings. This result is in line with our hypothesis and Edwards, et al. (2016). However, we also find that increases in financial constraints measured by the change of real Gross Domestic Product (GDP) and Initial Public Offering (IPO) volume as proxies macroeconomic constraints, has no significant effect on cash tax savings. This is a deviation from our hypothesis and Edwards, et al. (2016), but it can be traced from several factors. These factors include: (1) the change of corporate tax rate from 28 to 25 percent as fiscal policy after the impact of Global Financial Crisis 2008. It could reduce tax avoidance behaviour; (2) from capital market perspective, Indonesian Go Public Information Centre states that the purpose of the firms' Initial Public Offering (IPO) is not only to finance the firms' operation due to increases financial constraints, but also increase firm's value, improve corporate image, grow employee loyalty, maintain business continuity and get tax incentives; (3) The equity financing in Indonesia is more related to equity participation activities conducted among shareholders that's not listed on the stock 
or bond markets, e.g. private placement, joint venture, mergers and acquisitions.

This study extends tax avoidance literature in Indonesia by showing that firms facing increases in financial constraints measured by firm-specific level empirically avoid taxes by generating cash as source of financing, but it doesn't occur when measured by macroeconomics shocks. This study also contributes to the Indonesian Tax Authority by recommending considerations in mapping of taxpayers that will be audited by conducting risk analysis.

The remaining of this paper is organized as follows. Section 2 provides related literature and development of hypothesis. Section 3 describes the research design. Section 4 presents our main empirical result. Section 5 concludes.

\section{LITERATURE REVIEW AND HYPOTHESIS DEVELOPMENT}

According to Whited and Wu (2006) and Denis and Sibilkov (2010), the increase in financial constraints is an increase cost of external financing or the difficulty of accessing external fund. Platt and Platt (2002) argue that financial constraints represent the declining firm's financial condition prior to bankruptcy or liquidation. Kaplan and Zingales (1997) define financial constraints as a limitation of firms to get financing from external sources. The indication of financial constraints is the increasing cost of debt and cost of equity which is reflected in market-to-book ratio and cash flows (Fazzari et al., 1988).

In the condition of firms facing increases in financial constraints, debt and equity financing sources become more expensive or difficult to access, hence firms would seek alternative sources to fund their operations (Chen and Lai, 2012). The corporate tax burden is a non-discretionary burden set by the government, but the firms can implement various strategies to reduce cash paid to tax authority. Reducing the firm's tax burden for cash is an alternative financing source when firms facing increases in financial constraints (Edwards, et al., 2016).

Tax avoidance through cash tax savings is one of strategies conducted by the firms to minimize the amount of tax paid to government (Whited and Wu, 2006). Edwards et al. (2016) argue that cash tax savings has a cost of financing in the form of implicit discount rate depending on: (1) the amount of cash that can be saved; (2) time of repayment if using deferral strategies; (3) interest and/or penalty imposed by the tax authority if detected as tax evasion; (4) direct costs to implement cash tax savings strategy. Moreover, there is a possibility of the declining of firms' reputation in the long run.

In general, firms are always trying to make efficiency to generate cash, so it can be said that the firms are always in a state of financial constraints. However, they do not always generate cash through tax avoidance as a result of the financial constraints. When macroeconomics shocks occurred, such as economic crises, all firms will be affected. Therefore, they tend to generate cash through tax 
avoidance. Similarly, if firms facing continuous operational losses (Altman, 1968), or do not have the capability to finance their investment (Kaplan and Zingales, 1997), they have high potential for generating cash through tax avoidance too.

Law and Mills (2015) conclude that financial constraints measured by the count of negative word on financial statements has positive effect on tax aggressiveness. Edwards, et al., (2016) argue that the increases in financial constraints measured by firm-specific and macroeconomic shocks has positive effect on cash tax savings. Leone (2008) also explained that cash tax savings are preferred by firms in difficult economic conditions. Therefore, we hypothesize that:

$\mathrm{H1}$ : Increases in financial constraints positively affect cash tax savings.

\section{RESEARCH DESIGN}

\subsection{Sample Selection and Data Source}

Our sample initially consists of 559 publicly-listed Indonesian firms for the year 2009 to 2016. The selection of the time period is carried out considering post Global Financial Crisis's impact on Indonesia in 2008. However, the sample is reduced to 60 firms after excluding firms which fall into the following categories: firms that belong to financial sector; firms with negative pretax income; firms with majority of income are subjected to final income taxes; firms with Cash ETR less than 0 and more than 1 ; firms with incomplete data variables studied. Finally, all financial data are hand-collected from the financial reports of the sample firms.

Firms belong to financial services are excluded in this study because their business sector has its own specific rules in its financial ratios compared to other business sectors (Taylor and Richardson, 2013). Firms with negative pretax income are also excluded in this study because more profitable firms are encouraged to avoid taxes, so that the firms included in this study are those that have positive pretax income (Edwards, et al., 2016). Firms whose majority of the transaction is subject to final income tax are excluded considering the final income tax is different in terms of rate and administration from corporate income tax. Additional exception for firms whose Cash ETR is less than 0 and more than 1 because of less interpretable and comparable than others firm (Stickney and Newberry, 1997). In addition, exceptions for firm with incomplete data variables which do not submit financial statements within year 2009 - 2016 or missing data are also added because we prefer balanced panel data in this research, so that a complete data trend is required

\subsection{Base Regression Method}

To examine the effect of increases in financial constraints on cash tax savings, we use Ordinary Least Square (OLS) regression. 


\section{$\Delta$ CashETR $_{i, t+1}=\beta_{0}+\beta_{1}$ COnstraints $_{i, t}+\beta k \Delta$ PROA $_{i, t+1}+\beta k \Delta$ LnSales $_{i, t+1}+$ \\ $\beta k \Delta$ SalesGrowth ${ }_{i, t+1}+\beta k \Delta B M_{i, t+1}+\beta k \Delta$ Leverage $_{i, t+1}+\beta k \Delta P P E_{i, t+1}+$ \\ $\beta k \Delta$ Inventory $i, t+1+\beta k \Delta$ DiscAccruals $_{i, t+1}+\beta k \Delta$ NOL $_{i, t+1}+$

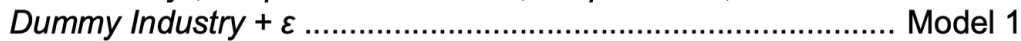

where $\mathrm{i}=$ firms $1-60 ; \mathrm{t}=$ financial years beginning 2009; $\boldsymbol{\Delta}$ CashETR = change in firm's Cash ETR. Cash ETR is measured as ratio of cash taxes paid to pretax income; $\boldsymbol{\Delta}$ Constraints $=$ change in financial constraints faced by the firm measured by using two firm-specific constraints, $\Delta$ Altman Z-Score and $\boldsymbol{\Delta}$ Kaplan Zingales (KZ) Index, and two macroeconomic constraints, $\Delta \mathrm{GDP} \%$ and $\Delta \mathrm{PPOV}$ olume; $\triangle \mathrm{PROA}=$ change in ratio firm's pretax return on asset; $\Delta \mathrm{L}$ nSales $=$ change in natural log of sales; $\Delta$ SalesGrowth $=$ change in growth in sales; $\boldsymbol{\Delta} \mathrm{BM}=$ change in ratio of book value of equity to market value of equity; $\Delta$ Leverage $=$ change in ratio of total debt to total assets; $\triangle \mathrm{PPE}=$ change in ratio of gross property, plant, and equipment to lagged total assets; $\Delta$ Inventory $=$ change in ratio of inventory to lagged total assets; $\Delta$ DiscAcc $=$ change in pretax performance-matched modified Jones discretionary accruals estimated using the methodology developed in Frank, et al. (2009); $\boldsymbol{\Delta} \mathrm{NOL}=$ change in loss carry-forward scales by lagged total assets; Dummy Industry = industry sector dummy variable of 1 if the firm is represented in the particular Jakarta Stock Exchange Industrial Classification (JASICA) category, and 0 otherwise; $\varepsilon=$ error term.

\subsection{Dependent Variable}

Our dependent variable is cash tax savings which is represented by $\boldsymbol{\Delta}$ CashETR. Hanlon and Heitzman (2010) mention that in the review of tax literature, it is important to select a tax avoidance measure appropriately to the research question and not simply apply a laundry list of measures. Edwards, et al. (2016) state that firm's cash ETR is the most direct measure of firm's cash tax burden because tax avoidance that decreases a firm's cash tax burden will have a direct impact on firm's cash ETR. The lower cash ETR means the higher tax avoidance, and the lower $\boldsymbol{\Delta}$ CashETR means the higher cash tax savings. We measure $\Delta$ CashETR in year t+1 (beginning from year 2010) because firms generally need time to plan and implement tax avoidance strategies (Edwards, et al., 2016).

\subsection{Independent Variable}

Our independent variable is the changes in financial constraints $(\boldsymbol{\Delta}$ Constraints) which is represented by four proxies which consists of $\Delta$ Altman Z-Score, $\neg \boldsymbol{\Delta} \mathrm{KZ}$ Index, $\neg \boldsymbol{\Delta G D P \%}$ and $\boldsymbol{\Delta}$ IPOVolume. We follow Edwards, et al. (2016) to determine the change in financial constraints. We measure the change in financial constraints in year $t$ (i.e. from year t-1 to t) beginning from year 2009 to 2015 but the effect of those changes on dependent and control variable is from 
year 2010 to 2016. Higher value of $\boldsymbol{\Delta}$ Constraints represent an increase in financial constraints.

Firm-specific constraints consist of $\Delta$ Altman Z-Score to capture financial distress, and $\boldsymbol{\Delta} K Z$ Index to capture investment-related constraints. These distribution data are highly skewed (see Table 1) so that we use decile rank values from 0 to 9 . Therefore, $\Delta$ Altman $Z$-Score and $\Delta K Z$ Index are called Rank $\boldsymbol{\Delta} Z$ and Rank $\boldsymbol{\Delta} K Z$. The formula of these proxies arewhere $t=$ financial years from 2009 to 2015; EBIT = Earning before Interest and Taxes; Working Capital $=$ Current Assets - Current Liabilities; Cash Flow $=$ net income from operating activities; $\mathrm{K}=$ property, plant, and equipment; $\mathrm{Q}=$ tobin's $\mathrm{q}$ formula. The calculation of $\Delta$ Altman Z-Score is times by -1 to be consistent with other proxies so that higher values represent increase in financial constraints.

$$
\text { We also measure for }
$$

macroeconomic constraints using two alternatives measured by Edwards, et al. (2016) which are $\boldsymbol{\Delta}$ GDP\% and $\Delta$ IPOVolume. $\Delta \mathrm{GDP} \%$ is based on real gross domestic product in year 2010 from World Bank. It is intended to measure economic contraction, during which external funding is often more limited and firms are more financially constrained. $\Delta \mid$ POVolume is based on the volume of the firms that conducted Initial Public Offering (IPO) from Indonesia Stock Exchange (IDX). It is intended to measure frothiness equity market, during which external equity funding is often more limited. These proxies are times by -1 so that higher values represent an increase in financial constraints.

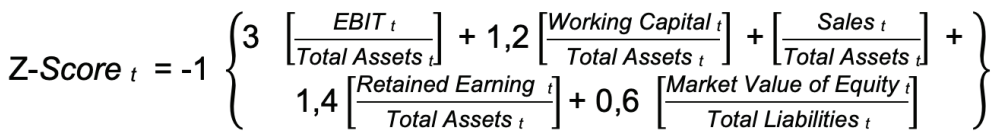

$$
\begin{aligned}
& K Z \text { Index }_{t}=-1\left(\frac{\text { Cash Flow } t}{K_{t}}\right)+0,28 Q+3,13\left(\frac{\text { Debt }_{t}}{\text { Total Capital }_{t}}\right)-39,36\left(\frac{\text { Deviden }_{t}}{K_{t}}\right)-1,31\left(\frac{\text { Cash }_{t}}{K_{t}}\right)
\end{aligned}
$$

\section{formula 2}

\subsection{Control Variables}

To control for other effects on cash tax savings, we include the following control variables in our regression model: change of pretax return on assets $(\Delta \mathrm{PROA})$, change of firm's size ( $\boldsymbol{\Delta}$ LnSales), change in economic activity ( $\boldsymbol{\Delta}$ SalesGrowth), change firm's expected future economic growth $(\boldsymbol{\Delta}$ BM), change in leverage ratio ( $\boldsymbol{\Delta}$ Leverage), change in capital assets ( $\boldsymbol{\Delta}$ $P P E)$, change in firm's inventory intensity ( $\boldsymbol{\Delta}$ Inventory), change in financial reporting practices ( $\Delta$ DiscAcc), change in the presence of net operating loss carryforwards $(\boldsymbol{\Delta N O L})$, and industry sector effect (Dummy Industry). We measure control variables in year $t+1$ following the delay effect of dependent variable due to increase in financial constraints.

Following Gupta and Newberry (1997), we expect positive correlation between $\triangle$ PROA as profitability control and $\boldsymbol{\Delta}$ CashETR as cash tax savings. 
Recent studies generally argue that firm size can have two opposing directions on tax avoidance. On one hand, Siegfried (1974) argues that the larger firm would have lower effective tax rates than smaller because they have greater resources with which to influence tax policy. On the other hand, Zimmerman (1983) argues that the larger firms have higher tax rates than other firms because they have greater government scrutiny. Therefore, we make no directional prediction for firm size effects on cash tax savings. We also include $\boldsymbol{\Delta}$ SalesGrowth as the additional control for any changes in economic activity on cash ETRs and no directional effect for it (Edwards, et al., 2016).

We also come after Edwards, et al. (2016) in using $\Delta \mathrm{BM}$ as a proxy to capture the change in the firm's expected future economic growth. We make no directional prediction for it. Gupta and Newberry (1997) explain that firm's debt ratio could influence tax avoidance strategies because of interest expense as deduction for taxable income, thus we make negative prediction for it. We include $\triangle P P E$ to control accelerated depreciation expense for taxation purpose (Stickney and McGee, 1982), and make negative direction for it. Following Edwards, et al. (2016), we include $\boldsymbol{\Delta}$ Inventory as proxy for changes in firm's inventory intensity. The higher inventory intensity does not typically generate tax planning opportunities, thus we anticipate positive association between $\boldsymbol{\Delta}$ Inventory and $\boldsymbol{\Delta}$ CashETR.
Frank, et al. (2009) find that firms which exhibit more aggressive financial reporting practices are more tax aggressive. Therefore, we include performance-matched pretax discretionary accruals ( $\Delta$ DiscAcc) to control for changes in financial reporting practices. We make negative association between $\Delta$ DiscAcc and $\boldsymbol{\Delta}$ CashETR. Chen, et al. (2010) argue that firms have lower tax rates because they are able to utilize the loss carryforward to reduce taxable income, thus we make negative association between $\boldsymbol{\Delta} \mathrm{NOL}$ and $\boldsymbol{\Delta}$ CashETR. We also incorporate industry fixed-effects in our regression model to control industry sectors. All of the control variables are in accordance to Edwards, et al. (2016), but we exclude $\Delta R \& D$ (change in R\&D Expense) to the model's equation because the Statement of Financial Accounting Standard No. 19 on Intangible Assets does not require to disclose R\&D expense in the firm's financial statements. We also exclude $\boldsymbol{\Delta}$ Foreign (change in foreign income) due to the absence of obligation to submit detailed information about foreign income in the firm's financial statements based on Regulation of the Indonesia Capital Market Agency (Bapepam LK) No. KEP-347/BL/2012.

\section{EMPIRICAL ANALYSIS}

\subsection{Descriptive Statistics}

Table 1 presents descriptive statistics for all variables used in this study. 
Table 1

Descriptive Statistics

\begin{tabular}{ccccccc}
\hline Variables & $\mathbf{n}$ & Mean & Minimum & Maximum & Median & Std. Dev. \\
\hline $\begin{array}{c}\text { Tax Measure } \\
\text { MCashETR }\end{array}$ & 360 & 0.00059 & -0.88785 & 0.83367 & 0.00000 & 0.18387
\end{tabular}

Firm-Specific Financial Constraints Measures

$\begin{array}{lrrrrrr}\Delta A / t \operatorname{man}-Z^{*} & 360 & 0.14673 & -246.91196 & 246.80968 & 0.03965 & 18.59234 \\ \Delta K Z^{*} & 360 & 0.02495 & -69.36451 & 96.65628 & 0.01043 & 13.66353\end{array}$

Macroeconomic Financial Constraints Measures

$\begin{array}{lllrrrr}\Delta G D P \% & 360 & -0.06065 & -0.08696 & -0.04876 & -0.05794 & 0.01276 \\ \Delta I P O V o l u m e & 360 & -0.33333 & -10.00000 & 8.00000 & 1.00000 & 7.23655\end{array}$

Control Variables

$\begin{array}{lrrrrrr}\Delta P R O A & 360 & -0.01035 & -0.40315 & 0.40199 & -0.00668 & 0.07138 \\ \Delta \text { LnSales } & 360 & 0.11144 & -0.84246 & 1.58988 & 0.09674 & 0.18241 \\ \Delta \text { SalesGrowth } & 360 & -0.00990 & -2.87472 & 3.68322 & -0.02028 & 0.38210 \\ \Delta B M & 360 & -0.00295 & -0.83959 & 0.43797 & -0.00173 & 0.07192 \\ \Delta \text { Leverage } & 360 & 0.00454 & -0.33663 & 0.36693 & -0.00148 & 0.06475 \\ \Delta P P E & 360 & -0.00633 & -0.82573 & 0.94036 & -0.00619 & 0.13212 \\ \Delta \text { Inventory } & 360 & -0.00566 & -0.32844 & 0.18457 & 0.00000 & 0.06402 \\ \text { ANOL } & 360 & 0.00052 & -0.03048 & 0.04136 & 0.00000 & 0.00543 \\ \Delta \text { DiscAcc } & 360 & -0.00156 & -0.50177 & 0.32199 & 0.00133 & 0.09549\end{array}$

*while reporting descriptive statistics, we do not decile rank values between 0 and 9

Variable definitions: $\boldsymbol{\Delta}$ CashETR $=$ the change in the ratio of cash tax paid to pretax income; Altman- $Z=-1$ times the change of Altman (1968) Z-score as calculated in formula $1 ; \boldsymbol{\Delta K Z}=$ the change of Kaplan and Zingales (1997) Index as calculated in formula 2; $\boldsymbol{\Delta} \mathrm{GDP} \%=-1$ times the percentage change of real GDP adjusted by inflation index based year 2010 from World Bank; $\Delta \mathrm{IPOVolume}=-1$ times the change in the number of IPOs during the year from on IDX data; $\triangle \mathrm{PROA}=$ the change in the ratio of pretax income to lagged total assets; $\boldsymbol{\Delta} \mathrm{LnSales}=$ the change in the natural

log of sales $\boldsymbol{\Delta}$ SalesGrowth $=$ the change in the growth in sales; $\Delta \mathrm{BM}=$ the change in the ratio of the book value of equity to the market value of equity; $\Delta$ Leverage $=$ the change in the ratio of total debt to total assets; $\triangle \mathrm{PPE}=$ the change in the ratio of gross PPE to lagged total assets; $\Delta$ Inventory $=$ the change in the ratio of inventory to lagged total assets; $\boldsymbol{\Delta} \mathrm{NOL}=$ the change in loss carry-forward scales by lagged total assets; $\Delta$ DiscAcc $=$ the change in pretax performance-matched modified Jones discretionary accruals estimated using the methodology developed in Frank et al. (2009). 
4.2 Regression Result and Discussion

Table 2

The Relation between Changes in Financial Constraints and Tax Avoidance

Firm-Specific

Macroeconomic

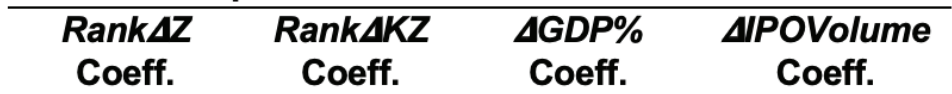

\begin{tabular}{|c|c|c|c|c|c|}
\hline Variable & Pred. & (Std. Err.) & (Std. Err.) & (Std. Err.) & (Std. Err.) \\
\hline Intercept & $?$ & $\begin{array}{l}0.04039 \\
0.02266\end{array}$ & $\begin{array}{c}0.17216 \\
(0.19999)\end{array}$ & $\begin{array}{c}-0.03871 \\
(0.03883)\end{array}$ & $\begin{array}{c}-0.00533 \\
(0.16299)\end{array}$ \\
\hline$\Delta$ Constraints & - & $\begin{array}{c}-0.01063^{*} \\
(0.00349)\end{array}$ & $\begin{array}{l}-0.00555^{\star} \\
(0.00294)\end{array}$ & $\begin{array}{l}-0.55525 \\
(0.55997)\end{array}$ & $\begin{array}{l}-0.00136 \\
(0.00128)\end{array}$ \\
\hline$\triangle P R O A$ & - & $\begin{array}{l}-1.26784^{*} \\
(0.20444)\end{array}$ & $\begin{array}{l}-1.20853^{*} \\
(0.19410)\end{array}$ & $\begin{array}{l}-1.17793^{*} \\
(0.19364)\end{array}$ & $\begin{array}{l}-1.18942^{*} \\
(0.19251)\end{array}$ \\
\hline ALnSales & ? & $\begin{array}{l}-0.01147 \\
(0.06026)\end{array}$ & $\begin{array}{c}0.00984 \\
(0.06273)\end{array}$ & $\begin{array}{l}-0.01125 \\
(0.06620)\end{array}$ & $\begin{array}{c}-0.01305 \\
(0.06236)\end{array}$ \\
\hline$\Delta$ SalesGrowth & ? & $\begin{array}{c}0.02703 \\
(0.34146)\end{array}$ & $\begin{array}{c}0.11337 \\
(0.35080)\end{array}$ & $\begin{array}{c}0.01260 \\
(0.03630)\end{array}$ & $\begin{array}{c}0.01217 \\
(0.03598)\end{array}$ \\
\hline$\triangle B M$ & ? & $\begin{array}{l}-0.20796^{*} \\
(0.10958)\end{array}$ & $\begin{array}{l}-0.21512^{*} \\
(0.11476)\end{array}$ & $\begin{array}{l}-0.24209^{*} \\
(0.11589)\end{array}$ & $\begin{array}{l}-0.23560^{*} \\
(0.11813)\end{array}$ \\
\hline$\Delta$ Leverage & - & $\begin{array}{c}0.11475 \\
(0.15413)\end{array}$ & $\begin{array}{c}0.11379 \\
(0.15335)\end{array}$ & $\begin{array}{c}0.10563 \\
(0.15532)\end{array}$ & $\begin{array}{c}0.11679 \\
(0.15641)\end{array}$ \\
\hline$\triangle P P E$ & - & $\begin{array}{c}0.00518 \\
(0.54431)\end{array}$ & $\begin{array}{l}-0.00524 \\
(0.05494)\end{array}$ & $\begin{array}{l}-0.00350 \\
(0.05621)\end{array}$ & $\begin{array}{c}0.00060 \\
(0.05684)\end{array}$ \\
\hline Alnventory & + & $\begin{array}{c}0.54543 \\
(0.13572)\end{array}$ & $\begin{array}{c}0.12644 \\
(0.13618)\end{array}$ & $\begin{array}{l}0.13568 \\
0.13699\end{array}$ & $\begin{array}{c}0.12632 \\
(0.13847)\end{array}$ \\
\hline$\triangle D i s c A c c$ & - & $\begin{array}{c}0.34705 \\
(0.10661)\end{array}$ & $\begin{array}{c}0.00141 \\
(0.10878)\end{array}$ & $\begin{array}{c}0.01580 \\
(0.11079)\end{array}$ & $\begin{array}{c}0.01248 \\
(0.10947)\end{array}$ \\
\hline$\triangle N O L$ & - & $\begin{array}{l}-1.77831 \\
(2.85352)\end{array}$ & $\begin{array}{l}-0.52596 \\
(2.90922)\end{array}$ & $\begin{array}{l}-0.59431 \\
(2.88325)\end{array}$ & $\begin{array}{l}-0.60796 \\
(2.86226)\end{array}$ \\
\hline $\begin{array}{l}\text { Dummy } \\
\mathrm{R}^{2}(\%)\end{array}$ & ? & $\begin{array}{c}\text { Yes } \\
27.82\end{array}$ & $\begin{array}{c}\text { Yes } \\
26.20\end{array}$ & $\begin{array}{c}\text { Yes } \\
25.63\end{array}$ & $\begin{array}{c}\text { Yes } \\
25.75\end{array}$ \\
\hline $\mathrm{n}$ & & 360 & 360 & 360 & 360 \\
\hline
\end{tabular}

*denote significant at 5 percent one-tail for all predictions. Regression model includes untabulated industry fixed effects that represented in the particular JASICA category. Huber-White robust standard errors clustered by firm are used to control for serial correlation and heteroscedasticity (Gujarati and Porter, 2009).

Table 2 presents the results OLS regression using equation in model 1 ,

which are $\boldsymbol{\Delta}$ CashETR as dependent variable, and various measures of changes in financial constraints as independent variables. We find negative and significant coefficient ( $p$-values $<0,05)$ on firm-specific constraints (Rank $\boldsymbol{\Delta} Z$ and Rank $\boldsymbol{\Delta} K Z$ ), but negative and insignificant coefficient on macroeconomic constraints ( $\Delta \mathrm{GDP} \%$ and $\boldsymbol{\Delta}$ IPOVolume). The firm-specific constraints are consistent with $\mathrm{H} 1$ and Edwards, et al. (2016) and 
suggest that firms increase cash tax savings to generate internal fund in response to increases in financial constraints. Nevertheless, the macroeconomic constraints are inconsistent. Its inconsistency can be caused by several factors. First, government had stimulated the economic growth by tax rates cut in response to Global Financial Crisis 2008 impact. According to article 17 paragraph 2a of UU no. 7 Year 1983 as lastly amended by UU no. 36 Year 2008 regarding Income Tax, corporate income tax reduced from $28 \%$ to $25 \%$ beginning in the fiscal year of 2010. Although many firm had problem with liquidity, insolvency, and financially constraints during the crisis, they didn't tend to generate cash through tax avoidance because government had spurred the economics through this policy.

Second, from capital market perspective, Indonesian Go Public Information Centre states that the purpose of the firms' Initial Public Offering (IPO) is not only to finance the firm's operation due to increases in financial constraints, but also to increase firm value, improve corporate image, grow employee loyalty, maintain business continuity and get tax incentives. Pagano et al. (1998) argues that IPO is likely increasing firm's size and industry's market to book ratio, thus, firms appear to go public not to finance future investment and growth, but to rebalance their accounts after high investment and growth.

Third, based on Indonesia Economy Outlook $(2009,59)$ stated that the issuance of new shares through IPO is not always in line with the Jakarta Composite Index (JSX). Moreover, equity financing in Indonesia is more related to equity participation activities conducted among shareholders that have not been listed on the stock or bond markets, e.g. private placement, joint venture, mergers and acquisitions. Therefore, macroeconomics shocks related to equity financing is not reflected in the IPO volume in Indonesia.

The remaining variables included in regression are generally consistent with the expectations. We find a negative and significant coefficient on $\triangle \mathrm{PROA}$ and $\Delta \mathrm{BM}$. We can calculate the economic significance of the result of firm-specific constraints (Rank $\boldsymbol{\Delta Z}$ and Rank $\boldsymbol{\Delta} K Z$ ) to magnify the loss effect of Indonesia tax revenue.

Table 3

The Economic Significance of Cash Tax Savings

\begin{tabular}{|l|c|c|c|c|c|c|c|}
\hline Measure & Coeff. & $\begin{array}{c}\text { Decile } \\
\text { Increase }\end{array}$ & $\begin{array}{c}\Delta \text { in Cash } \\
\text { ETR }\end{array}$ & $\begin{array}{c}\text { Pretax } \\
\text { Income }\end{array}$ & $\begin{array}{c}\text { Tax } \\
\text { Savings }\end{array}$ & OCF & $\begin{array}{c}\% \text { of } \\
\text { OCF }\end{array}$ \\
\hline Rank $\boldsymbol{\Delta K Z}$ & -0.00555 & 1 & $-0.55 \%$ & $1,599.19$ & 8.87 & $1,485.00$ & $0.60 \%$ \\
\hline Rank $\boldsymbol{\Delta K Z}$ & -0.00555 & 9 & $-4.99 \%$ & $1,432.59$ & 71.55 & $1,290.66$ & $5.54 \%$ \\
\hline Rank $\boldsymbol{\Delta Z}$ & -0.01063 & 1 & $-1.06 \%$ & $1,509.26$ & 16.04 & 868.36 & $1.85 \%$ \\
\hline Rank $\boldsymbol{\Delta Z}$ & -0.01063 & 9 & $-9.57 \%$ & $2,507.27$ & 239.89 & $2,331.50$ & $10.29 \%$ \\
\hline
\end{tabular}


The "Measure" column list the proxies of firm-specific constraints. The "Coeff."column presents the estimated coefficient from the regressions presented in table 2. The "Decile Increase" column presents the change in constraint used to estimate the economic significance. The " $\boldsymbol{\Delta}$ in Cash ETR" column presents the product of "Coeff." and "Decile Increase". The "Pretax Income" column presents the mean firms' pretax income included in the samples. The "Tax Savings" column presents the product of " $\boldsymbol{\Delta}$ in Cash ETR" column and "Pretax Income". The "OCF" column presents the mean operating cash flows for firms included in the samples. "The "\% of OCF" column presents the ratio of "Tax Savings" to "OCF".

Table 3 shows the estimation of firms' cash tax savings on the 1st and 9th decile of $\boldsymbol{\Delta}$ Constraints (Rank $\boldsymbol{\Delta} K Z$ and Rank $\boldsymbol{\Delta} \mathbf{Z}$ ). It is used to determine the relatively small and significant effect on changes in financial constraints. The average firms in the observation with increases in financial constraints at 1st decile (Rank $\boldsymbol{\Delta} K Z=1$ or $\operatorname{Rank} \boldsymbol{\Delta} Z \mathbf{Z}=1$ ) decreased cash ETR by 0,55 to 1,06 percent, whereas at 9th decile (Rank $\boldsymbol{\Delta}$ $\mathrm{KZ}=9$ or RanktZ = 9) decreased cash ETR by 4,99 to 9,57 percent. The declining 9th decile is equivalent to cash tax savings 71,55 to 239,89 billion Indonesian Rupiahs, equivalent to 5,54 to 10,29 percent of operating cash flows. This estimate concludes that the firm facing increases in financial constraints measured by firm-specific level tend to generate cash through tax avoidance. Thus it also substantially increases their operating cash flows.

\section{CONCLUSION}

This study examines the effect of increases in financial constraints on corporate tax avoidance behaviour through cash tax savings. By examining panel data on 60 sample firms listed on IDX from 2009 to 2016 using OLS regression, we conclude that increases in financial constraints measured by firm-specific level have significant positive effect on cash tax savings, but not significant if measured by macroeconomic constraints.

The firm-specific constraints result is consistent with our hypothesis and Edwards, et al. (2016), whereas the macroeconomic constraints result is inconsistent. However, this inconsistency can be caused by several factors i.e.: (1) the change of corporate tax rate from 28 to 25 percent as government policy after the impact of Global Financial Crisis 2008. It could reduce tax avoidance behaviour; (2) Indonesian Go Public Information Centre stated that the purpose of the firms' Initial Public Offering (IPO) is not only to finance the firms' operation due to increases financial constraints, but also increase firm's value, improve corporate image, grow employee loyalty, ability to maintain business continuity and tax incentives; (3) the equity financing in Indonesia is more related to equity participation activities conducted among shareholders that have not been listed on the stock or bond markets, e.g. private placement, joint venture, mergers and acquisitions. 
The tax avoidance effect is firms facing increased firm-specific constraints exhibit lower cash effective tax rates ranging from 0.55 to 9.57 percent which equate to between 0.60 and 10.29 percent of operating cash flows. It potentially impacts the government tax revenue relatively large amount 71.55 to 239.89 billion Indonesian Rupiahs.

This study presents new insight into tax avoidance literature in Indonesia by showing that firms facing increases in financial constraints measured by firm-specific level tend to generate cash through tax avoidance (cash tax savings), yet the result is not shown if measured by macroeconomics constraints. This study also useful for the Indonesian Tax Authority by recommending as a consideration in the mapping of taxpayers that will be audited by conducting risk analysis.

\section{LIMITATION OF THE RESEARCH AND SUGGESTION FOR THE FUTURE RESEARCH}

The limitation of this research comprises of:

a. The sample selection is based on the firms that are listed in the Indonesian Stock Exchange during the observation period, from 2009 to 2016. Using different samples, such as the firms that are not listed in the Indonesian Stock Exchange in different period, might derive a different conclusion.

b. Based on the Regulation of Indonesian Capital Market Agency (Bapepam LK) Number
KEP-347/BL/2012, there were no obligation to submit the detail information about foreign income in Financial Statement. Thus, we do not include the foreign income as a control variable.

c. Based on the Statement of Financial Accounting Standard No. 19 regarding Intangible Asset, there were no obligation to disclose Research \& Development Expense (R\&D Expense) in Financial Statement. Thus, we do not include R\&D Expenses as a control variable.

Our suggestion for the Future Research is to explore and dive into the cash tax savings strategies by using deferral tax planning mechanism. Moreover, the next research should also include the effect of cash holding to financial constraints in order to support the preliminary hypothesis.

\section{REFERENCES}

[1] Altman, E. I. (1968). Financial ratios, discriminant analysis and the prediction off corporate bankruptcy. The Journal of Finance, 23(4), 589-609. https://doi.org/10.2307/2978933

[2] Basri, M. C. (2013). A tale of two crises: Indonesia's political economy. JICA Research Institute Working Paper No. 57.

[3] Besley, T., \& Persson, T. (2014). Why do developing countries tax so little? The Journal of Economic Perspectives, 28(4), 99-120. https://doi.org/10.1257/jep.28.4.99

[4] Chen, C., \& Lai, S. (2012). Financial constraints and tax aggressiveness. Univesity of Auckland and Chinese University of Hong Kong, Working Paper.

[5] Darussalam. (2017). Tren, outlook dan tantangan pajak 2017. IAI Global. Retrieved accessed September 17, 2017, from 
http://iaiglobal.or.id/v03/files/file_publikasi/T ren,\%200utlook,\%20dan\%20Tantangan\%2 OPajak\%202017.pdf

[6] Degryse, H., \& Ongena, S. (2005). Distance, lending relationships, and competition. The Journal of Finance, 60(1), 231-266. https://doi.org/10.1111/j.1540-6261.2005.007 29.x

[7] Denis, D. J., \& Sibilkov, V. (2010). Financial constraints, investment, and the value of cash holdings. The Review of Financial Studies, 23(1), 247-269. https://doi.org/10.1093/rfs/hhp031

[8] Edwards, A., Schwab, C. M., \& Shevlin, T. J. (2013). Financial constraints and the incentive for tax planning. In 2013 American Taxation Association Midyear Meeting: New Faculty/Doctoral Student Session. http://papers.ssrn.com/abstract (Vol. 2216875)

[9] Edwards, A., Schwab, C. M., \& Shevlin, T. J. (2016). Financial constraints and cash tax savings. The Accounting Review, 91 (3), 859-881. https://doi.org/10.2308/accr-51282

[10] Fazzari, S. M., Hubbard, R. G., Petersen, B. C., Blinder, A. S., \& Poterba, J. M. (1988). Financing constraints and corporate investment. Brookings Papers on Economic Activity, 1, 141-195. https://doi.org/ 10.2307/2534426

[11] Frank, M. M., Lynch, L. J., \& Rego, S. O. (2009). Tax reporting aggressiveness and its relation to aggressive financial reporting. The Accounting Review, 84, 467-496. https://doi.org/10.2308/accr.2009.84.2.467

[12] Glick, R., \& Spiegel, M. M. (2010). Asia and the global financial crisis: Conference summary. Economic Review-Federal Reserve Bank of San Francisco, 69

[13] Gujarati, D. N., \& Porter, D. C. (2009). Basic econometrics (5th ed.). New York: The McGraw-Hill.

[14] Gupta, S., \& Newberry, K. (1997). Determinants of the variability in corporate effective tax rates: Evidence from longitudinal data. Journal of Accounting and Public Policy, 16(1), 1-34. https://doi.org/10.1016/S0278-4254(96)0005 5-5

[15] Hanlon, M., \& Heitzman, S. (2010). A review of tax research. Journal of Accounting and Economics, $\quad 50(2), \quad$ 127-178. https://doi.org/10.1016/j.jacceco.2010.09.002 [16] Indonesia Economic Outlook. (2009). 2009 to 2014: Krisis finansial global dan dampaknya terhadap perekonomian Indonesia. Direktorat Riset Ekonomi dan Kebijakan Moneter. Retrieved Desember 20, 2017,from http://www.bi.go.id/id/publikasi /kebijakan-moneter/outlookekonomi/Pages / oei_0109.aspx

[17] Indonesian Go Public Information Centre. (n.d.) Manfaat go public. Retrieved Desember 19, 2017, from https://gopublic.idx.co.id/2016/06/22/manfa at-go-public/

[18] Indonesia Stock Exchange. (n.d.). Laporan keuangan dan tahunan perusahaan tercatat. Retrieved September 05, 2017, from http://idx.co.id/id-d/beranda/perusahaanter catat/laporankeuangandantahunan.aspx

[19] Kaplan, S. N., \& Zingales, L. (1997). Do investment cash flow sensitives provide useful measure of financing constraints? Quarterly Journal of Economics, 112(1), 169-215. https://www.jstor.org/stable/ 2951280

[20] Law No. 7 of 1983 regarding Income Tax as amended several times and lastly by Law Number 36 of 2008.

[21] Law, K. K. F., \& Mills, L. F. (2015). Taxes and financial constraints: evidence from linguistic cues. Journal of Accounting Research, 53(4), 777-819. https://doi.org/10.1111/1475-679X. 12081

[22] Leone, M. (2008). There's a cash machine in your tax department. CFO. Retrieved September 18, 2017, from http://ww2.cfo.com/accountingtax/2008/12/ theres-a-cash-machine-in-your-taxdepartment

[23] Pagano, M., Panetta, F., \& Zingales, L. (1998). Why do companies go public? An empirical analysis. The Journal of Finance, 53(1), 27-64. https://doi.org/10.1111/0022-1082.25448

[24] Petersen, M. A., \& Rajan, R. G. (2002). Does distance still matter? The information revolution in small business lending. The journal of Finance, 57(6), 2533-2570. https://doi.org/10.1111/1540-6261.00505 
[25]Regulation of Indonesia Capital Market Agency (Bapepam LK) No. KEP-347/BL/2012

[26]Setiyaji, G., \& Amir, H. (2005). Evaluasi kinerja sistem perpajakan Indonesia. Jurnal Ekonomi, 10(2), 1-13.

[27] Siegfried, J. J. (1974). Effective average U. S. corporation income tax rates. National Tax Journal, 27(2), 245-259. https://doi.org/ 10.1086/NTJ41861946

[28] Statement of Financial Accounting Standard No. 19 regarding Intangible Asset. (2015). Indonesian Accounting Associate.

[29] Stickney, C. P., \& McGee, V. E. (1982). Effective corporate tax rates the effect of size, capital intensity, leverage, and other factors. Journal of Accounting and Public Policy, 1(2), 125-152. https://doi.org/10.1016/S02784254(82)80004-5

[30]Taylor, G., \& Richardson, G. (2013). The determinants of thinly capitalized tax avoidance structures: Evidence from Australian firms. Journal of International Accounting, Auditing and Taxation, 22(1), 12-25. https://doi.org/10.1016/j.intaccaudtax. 2013.02.005

[31] Trinz, R. (2014). Last minute year-end 2014 tax-saving moves for corporations accounting today. Accountingtoday. Retrieved September 10, 2017, from http://www.accountingtoday.com/news/taxplanning/last-minuteyear-end-2014-tax-savi ng-moves-corporations-72995-1.html

[32]Wiratno, G. A. (2017). Sri Mulyani: Tax Ratio Indonesia Terendah. Warta Ekonomi. Retrieved December 20, 2017, from https://www.wartaekonomi.co.id/read12693 7/sri-mulyani-tax-ratio-indone sia-terendah.html

[33]Whited, T. M., \& Wu, G. (2006). Financial constraints risk. Review of Financial Studies, 19 (2), 531- 559. https://doi.org/10.1093/ rfs/hhj012

[34]World Bank. (n.d.). Tax revenue (\% of GDP). World Bank. Retrieved September 5, 2017, from http://data.worldbank.org/ indicator/ GC.TAX.TOTL.GD.ZS

[35]Zimmerman, J. L. (1983). Taxes and firm size. Journal of accounting and economics, 5, 119-149. https://doi.org/10.1016/0165-4101 (83) $90008-3$ 